

Pengaruh peningkatan suhu dan waktu pemberian pakan terhadap laju pengambilan pakan pada karang lunak Sarcophyton sp. dan Sinularia sp.

\title{
The effect of increasing temperature and feeding time on feeding rate of soft coral Sarcophyton sp. and Sinularia sp.
}

\author{
I Gusti Ayu Agung Mahayoni Aksari a , Ni Luh Watiniasih ${ }^{\text {b }}$ dan Widiastuti ${ }^{\text {a, }}$ * \\ a Program Studi Ilmu Kelautan, Fakultas Kelautan dan Perikanan, Universitas Udayana \\ ${ }^{b}$ Program Studi Biologi, Fakultas Matematika dan Ilmu Pengetahuan Alam, Universitas Udayana
}

\section{Abstrak}

Meningkatnya suhu rata-rata permukaan laut menyebabkan kerusakan ekosistem terumbu karang, salah satu akibatnya adalah menurunkan laju pengambilan pakan oleh karang lunak. Penelitian ini bertujuan untuk mengetahui perbedaan laju pengambilan pakan pada suhu berbeda antara karang lunak Sarcophyton sp. dan Sinularia sp., mengetahui pengaruh peningkatan suhu, waktu pemberian pakan serta interaksi pengaruh peningkatan suhu dan waktu pemberian pakan terhadap laju pengambilan pakan pada karang lunak Sarcophyton sp. dan Sinularia sp. Sampel karang lunak diperoleh dari hasil budidaya PT. Dinar Darum Lestari di Perairan Teluk Pegametan, Desa Sumberkima, Kabupaten Buleleng. Sampel fragmen karang diaklimatisasi selama 2 minggu sebelum eksperimen dilakukan dan diberi pakan 2 kali seminggu pada suhu $26^{\circ} \mathrm{C}$ (suhu kontrol). Perlakuan suhu dilakukan dengan menaikkan suhu air di akuarium $1^{\circ} \mathrm{C}$ setiap jam untuk mencapai suhu $31^{\circ} \mathrm{C}$ (suhu stres) dan selanjutnya suhu dipertahankan selama 5 hari. Masing-masing akuarium $\left(26^{\circ} \mathrm{C}\right.$ dan $\left.31^{\circ} \mathrm{C}\right)$ diberikan pakan Artemia salina pada hari kedua dan keempat dengan kepadatan 100 ekor per fragmen di pagi hari selama 3 jam. Sisa pakan diambil dengan pipet tetes lalu dihitung sampai sisa pakan pada gelas ukur tersebut habis. Hasil penelitian menunjukkan bahwa laju pengambilan pakan antara karang lunak Sarcophyton sp. dan Sinularia sp. tidak berbeda signifikan baik pada suhu kontrol maupun suhu stress. Hal ini diduga karena kedua jenis fragmen karang lunak memiliki toleransi suhu yang relatif sama. Peningkatan suhu mempengaruhi laju pengambilan pakan pada kedua jenis karang lunak secara signifikan. Tetapi, waktu pemberian pakan serta interaksi antara suhu dan waktu pemberian pakan tidak memberikan pengaruh yang signifikan terhadap laju pengambilan pakan. Kenaikan suhu diduga mempengaruhi metabolisme pada karang lunak, sehingga menurunkan kemampuan mengambil pakan. Stres yang dialami kedua jenis karang lunak ketika diinkubasi pada $31^{\circ} \mathrm{C}$ terus terjadi selama karang lunak diinkubasi pada suhu tersebut sehingga tidak mempengaruhi laju pengambilan pakan pada semua waktu pemberian pakan.

Kata kunci: karang lunak; Sarcophyton sp.; Sinularia sp.; peningkatan suhu; laju pengambilan pakan; waktu pemberian pakan

\begin{abstract}
Increased the mean sea surface temperatures cause damage to coral reef ecosystems, one of those mechanisms is reducing the feeding capacity in soft corals. This study aimed to examine the feeding rates of soft corals Sinularia sp. and Sarcophyton sp. at different temperatures to determine the effect of increasing temperature, feeding time and interaction between those factors on feeding rates of soft corals Sarcophyton sp. and Sinularia sp. Samples of Soft corals were obtained from the cultured of PT. Dinar Darum Lestari in Pegametan Bay Waters, Sumberkima village, Buleleng Regency. Before the experiment, coral fragments were acclimatized for 2 weeks and fed twice a week at $26^{\circ} \mathrm{C}$ (control temperature). The experiment started by increasing the water temperature in the aquarium at $1^{\circ} \mathrm{C}$ every hour to reach $31^{\circ} \mathrm{C}$ (stress temperature). Once the temperature reached, it kept for 5 days. Each aquarium $\left(26\right.$ and $\left.31^{\circ} \mathrm{C}\right)$ was fed by Artemia salina nauplii on the second and fourth days with density 100 animals/fragments for 3 hours in the morning. The remained prey was taken by Pasteur pipette and counted manually. The results showed that there was no significant difference in feeding rates in Sarcophyton sp. dan Sinularia sp. at both control and stress temperatures. It is argued that both soft corals relatively have the same temperature tolerance. The increased temperature significantly affected the feeding rate in both soft corals. However, feeding time and interaction between temperature and feeding time did not have a significant effect on the feeding rate. It is assumed that the increased temperature reduces the feeding rate in these soft corals. Moreover, these soft corals seem suffering from stress due to incubate in high temperature $\left(31^{\circ} \mathrm{C}\right)$ continuously, caused no significant difference in the feeding rates at all feeding times.
\end{abstract}

Keywords: soft coral; Sarcophyton sp.; Sinularia sp.; increased temperature; feeding rate; feeding time 
* Corresponding author: Program Studi Ilmu Kelautan, Fakultas Kelautan dan Perikanan, Universitas Udayana

Telp: +62.81236339523

e-mail: widiastutikarim@unud.ac.id

doi: https://doi.org/10.29103/aa.v7i2.2526

\section{Pendahuluan}

Karang lunak (Filum Cnidaria: Ordo Alcyonacea) merupakan organisme yang memiliki dua cara mendapatkan makanan yaitu secara langsung dan tidak langsung. Proses mendapatkan makanan secara langsung diperoleh dengan cara menangkap mangsa dengan tentakel yang dimiliki, sedangkan secara tidak langsung karang memperoleh nutrisi dari proses fotosintesis yang dilakukan zooxanthella (Muscatine et al. 1981). Menurut Burmester et al. (2018), nutrisi yang diperoleh karang lunak secara tidak langsung berperan dalam menghambat perluasan luka pada jaringan karang, sedangkan nutrisi yang diperoleh secara langsung dapat membantu pemulihan luka lebih cepat pada jaringan karang serta memfasilitasi fotosintesis yang dilakukan zooxanthella.

Kemampuan mendapatkan makanan secara langsung pada karang lunak bervariasi berdasarkan berbagai faktor, yaitu antara lain morfologi karang sesuai jenis karang lunak (Goldberg, 2018), tipe pakan (Migne dan Davoult, 2002), serta suhu perairan (Coma et al., 2015). Karang lunak Eunicella singularis (ordo Alcyonacea) yang hidup di perairan Laut Mediterania menunjukkan laju pengambilan pakan yang lebih tinggi dengan jenis pakan yang ukurannya beragam pada musim semi dibandingkan pada musim dingin ataupun musim gugur (Coma et al., 2015). Laju pengambilan pakan pada karang lunak Alcyonium digitatum dipengaruhi oleh tipe pakan (zooplankton) dan kecepatan aliran air yang menentukan transfer partikel (Migne dan Davoult, 2002). Diantara berbagai faktor yang mempengaruhi laju pengambilan pakan, suhu perairan memiliki pengaruh yang relatif besar, khususnya adanya kenaikan ratarata suhu permukaan laut dewasa ini. Menurut Coma et al. (2015) selain menyebabkan coral bleaching, kenaikan rata-rata suhu permukaan laut dapat mempengaruhi metabolisme karang lunak yaitu menurunkan kemampuan mencerna karang lunak sehingga dapat mempengaruhi laju pengambilan pakan pada karang lunak.

Karang lunak Sarcophyton sp. dan Sinularia sp. tersebar luas di perairan Indonesia, yaitu antara lain dapat ditemukan di perairan Tulamben, Bali (Ruwaimana, 2013) dan Biak Timur dimana biasanya melekat pada substrat dasar yang keras dan terkena gelombang (Manuputty, 2016). Karang lunak Sarcophyton sp. dan Sinularia sp. biasanya dapat ditemukan pada kedalaman 3 meter dengan kisaran suhu $25^{\circ} \mathrm{C}$ sampai $32^{\circ} \mathrm{C}$ (Akbar, 2016).

Karang lunak Sarcophyton ehrenbergi dan Sinularia sp. merupakan jenis karang lunak yang bersimbiosis dengan zooxanthella, dimana kedua jenis tersebut memiliki tipe zooxanthella yang sama (clade C) dan mampu bertahan hidup ketika diinkubasi pada suhu diatas $31^{\circ} \mathrm{C}$ (Strychar et al., 2005). Namun meningkatnya suhu rata-rata permukaan laut dapat menyebabkan kerusakan ekosistem terumbu karang (Surakusumah dan Wahyu, 2011). Secara khusus yaitu dapat mempengaruhi mekanisme pengambilan pakan pada karang lunak (Towle et al., 2015). Oleh sebab itu perlu dilakukan penelitian untuk mengetahui pengaruh peningkatan suhu dan waktu pemberian pakan terhadap laju pengambilan pakan pada karang lunak Sarcophyton sp. dan Sinularia sp.

\section{Bahan dan metode}

\subsection{Waktu dan Tempat}

Penelitian dilakukan pada Bulan Januari - Februari 2020 bertempat di Laboratorium IImu Kelautan, Fakultas Kelautan dan Perikanan, Universitas Udayana. Sampel karang lunak diperoleh dari hasil budidaya PT. Dinar Darum Lestari di Perairan Teluk Sumberkima, Kabupaten Buleleng.

\subsection{Prosedur Penelitian}

Beberapa tahap yang dilakukan pada penelitian ditunjukkan pada (Gambar 1).



Gambar 1. Tahapan penelitian

\subsection{Rancangan penelitian}

\subsubsection{Karang lunak Sarcophyton sp. dan Sinularia sp.}

Karang lunak yang digunakan yaitu Sarcophyton sp. dan Sinularia sp. masing - masing sebanyak 5 fragmen yang memiliki ukuran relatif sama yaitu $5 \mathrm{~cm}$ dengan ulangan masingmasing 5 per jenis karang lunak. Morfologi karang lunak Sarcophyton sp. diidentifikasi sesuai Manuputty (2002) yaitu memiliki rangka yang lentur dengan bentuk seperti jamur, dan bagian permukaan kepala dipenuhi polip-polip yang timbul (Aratake et al., 2012).

Identifikasi Sinularia sp. dilakukan berdasarkan morfologi yaitu berbentuk encrusting yang keras dan memiliki polip yang dapat memanjang dan mengkerut (Manuputty, 2002). Selain itu, sesuai deskripsi Van et al. (2013), Sinularia sp. tidak memiliki tentakel. Masing-masing sampel karang lunak Sarcophyton sp. dan Sinularia sp. berasal dari indukan yang berbeda. Sampel karang lunak yang diperoleh kemudian dibiarkan menempel pada pecahan karang di dalam akuarium. Karang lunak Sarcophyton sp. dan Sinularia sp. yang digunakan pada penelitian ini ditunjukkan pada Gambar 2.


Gambar 2. Karang lunak Sarcophytum sp. dan Sinularia sp. yang digunakan pada penelitian. 


\subsubsection{Tata letak akuarium}

Seluruh fragmen karang lunak diaklimatisasi pada akuarium berukuran $80 \times 30 \mathrm{~cm}$ yang diisi dengan air laut yang memenuhi $70 \%$ bagian akuarium selama 14 hari pada suhu $26^{\circ} \mathrm{C}$. Suhu $26^{\circ} \mathrm{C}$ merupakan suhu kontrol pada penelitian ini yang mengacu pada Ferrier et al. (2010) dan Hoogenboom et al. (2012). Selama aklimatisasi, karang lunak diberi pakan dua kali seminggu dengan nauplius $A$. salina yang ditetaskan 1 × 24 jam sejumlah 100 ekor sebelum masing - masing karang lunak dipindahkan ke akuarium pengamatan (Ferrier et al. 2010; Hoogenboom et al., 2012). Metode penetasan dilakukan dengan meletakkan telur $A$. salina dalam wadah berisi air laut dengan suhu minimal $25^{\circ} \mathrm{C}$ dan diberi aerasi (Migne dan Davoult, 2002).

Kemudian masing-masing fragmen karang lunak ditempatkan pada akuarium berukuran $20 \times 20 \mathrm{~cm}$. Pencahayaan menggunakan lampu LED dengan penyinaran 12 jam terang/12 jam gelap dan intensitas cahaya yaitu 300 lux (Ferrier et al. 2010). Selama eksperimen berlangsung, salinitas seluruh akuarium dipertahankan pada kisaran 38,5 -38,7 ppt dan $\mathrm{pH}$ pada kisaran 7,6 -7,8. Aerator digunakan untuk meningkatkan kelarutan oksigen yang ditempatkan di masing masing akuarium beserta bio ball. Pertukaran air di dalam akuarium dilakukan sekitar $20 \%$ dari volume air akuarium selama 3 hari sekali. Pengaturan akuarium pengamatan ditunjukkan pada Gambar 3.

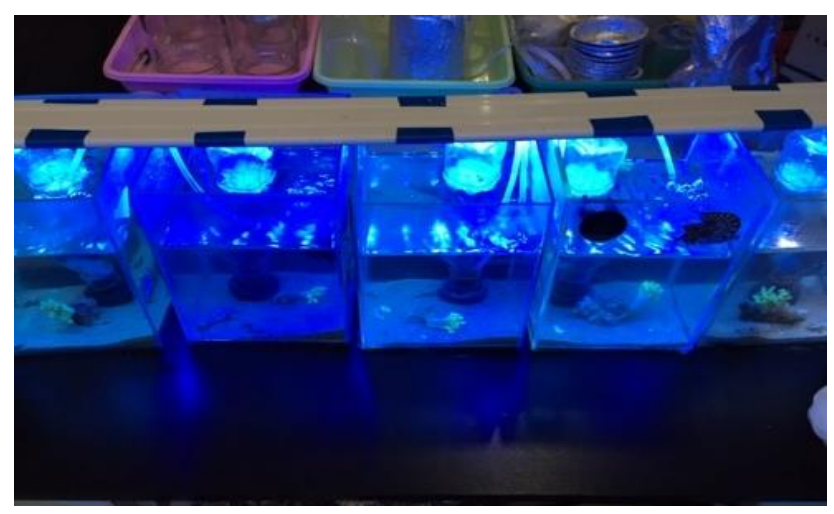

Gambar 3. Pengaturan peletakan akuarium pengamatan

\subsubsection{Eksperimen pengaruh peningkatan suhu dan waktu pemberian pakan terhadap laju pengambilan pakan pada karang lunak}

Pada perlakuan peningkatan suhu, suhu air di akuarium dinaikkan $1^{\circ} \mathrm{C}$ setiap jam untuk mencapai suhu $31^{\circ} \mathrm{C}$, selanjutnya suhu $31^{\circ} \mathrm{C}$ dipertahankan selama 5 hari (Ferrier et al., 2010). Masing-masing akuarium $\left(26^{\circ} \mathrm{C}\right.$ dan $\left.31^{\circ} \mathrm{C}\right)$ selama 5 hari diberikan pakan $A$. salina 2 kali. Pemberian pakan diberikan pada hari kedua dan keempat dengan kepadatan 100 ekor $A$. salina per fragmen di pagi hari sesuai dengan yang dilakukan Siang et al. (2009). Sebelum pemberian pakan, masing-masing fragmen dipindahkan ke gelas ukur dan kemudian diberi pakan. Pemberian pakan dilakukan setelah hampir semua polip pada fragmen karang lunak terlihat keluar. Gelas ukur yang berisi karang lunak tersebut ditempatkan dalam inkubator untuk mempertahankan masing - masing suhu perlakuan. Setelah 3 jam, sisa pakan diambil dengan pipet tetes lalu dihitung sampai sisa pakan pada gelas ukur tersebut habis (Ferrier et al. 2010). Masing-masing fragmen Karang lunak kembali dipindahkan ke akuarium setalah pemberian pakan.

\subsection{Analisis data}

Laju pengambilan pakan (feeding rate) karang lunak dihitung berdasarkan persamaan 1 (Siang et al., 2009):

Laju pengambilan pakan = kepadatan awal $A$. salina - kepadatan akhir $A$. salina $/$ durasi pengambilan pakan

\subsection{Analisis statistik}

Rata-rata laju pengambilan pakan pada karang lunak Sarcophyton sp. dan Sinularia sp. dianalisa secara statistik dengan Uji Independent Sample T-Test pada semua waktu pemberian pakan pada suhu $26^{\circ} \mathrm{C}$ dan $31^{\circ} \mathrm{C}$. Namun sebelum melakukan uji tersebut, terlebih dahulu dilakukan Uji Homogenitas untuk memenuhi asumsi pada Uji Independent Sample T-Test. Pengaruh peningkatan suhu, waktu pemberian pakan serta interaksi pengaruh peningkatan suhu dan waktu pemberian pakan terhadap laju pengambilan pakan pada karang lunak Sarcophyton sp. dan Sinularia sp. dianalisa secara statistik dengan uji Two Way ANOVA yang didahului Uji Normalitas untuk mengetahui distribusi data penelitian yang mewakili populasi untuk menentukan tingkat signifikansi residual standar data $(P>0,05$ dan $P<0,05)$ (Raharjo, 2019) dan Uji Homogenitas untuk mengetahui persebaran dari suatu data sama atau sejenis sehingga diketahui keakuratan dari perbedaan masing - masing data untuk menentukan tingkat signifikansi varian data $(P<0,05$ dan $P>0,05)$ (Raharjo, 2018).

\section{Hasil dan pembahasan}

\subsection{Hasil}

3.1.1. Pengaruh peningkatan suhu dan waktu pemberian pakan terhadap laju pengambilan pakan pada karang lunak Sarcophyton sp. dan Sinularia sp.

Peningkatan suhu berpengaruh signifikan (Tabel. 1) terhadap laju pengambilan pakan pada karang lunak Sarcophyton sp. yaitu ketika suhu dinaikkan $31^{\circ} \mathrm{C}$ terjad penurunan laju pengambilan pakan dibandingkan pada suhu kontrol, baik pada hari kedua dan hari keempat pemberian pakan. Hal serupa juga terjadi pada karang lunak Sinularia sp. dimana laju pengambilan pakan menurun ketika suhu dinaikkan menjadi $31^{\circ} \mathrm{C}$ baik pada hari kedua dan hari keempat $(P<0,05)$. Namun, waktu pemberian pakan tidak memberikan pengaruh yang signifikan terhadap laju pengambilan pakan pada kedua perlakuan suhu. Hal ini ditunjukkan pada karang lunak Sarcophyton sp. dimana pemberian pakan pada hari kedua dan hari keempat tidak berpengaruh signifikan $(P=0,255)$ terhadap laju pengambilan pakan pada kedua suhu. Kondisi yang sama juga terdapat pada karang lunak Sinularia sp. dimana pemberian pakan pada hari kedua dan hari keempat tidak berpengaruh signifikan $(P=0,150)$ terhadap laju pengambilan pakan pada kedua suhu.

Tabel 1

Analisis two-way Anova.

\begin{tabular}{cccccc}
\hline Karang lunak & Source & Df & Mean Square & $F$ & $P$ \\
\hline \multirow{3}{*}{ Sarcophyton sp. } & suhu & 1 & 64,8 & 112,696 & 0,000 \\
& waktu & 1 & 0,8 & 1,391 & 0,255 \\
& waktu * suhu & 1 & 0 & 0 & 1,000 \\
\hline \multirow{3}{*}{ Sinularia sp. } & suhu & 1 & 51,2 & 146,286 & 0,000 \\
& waktu & 1 & 0,8 & 2,286 & 0,150 \\
& waktu * suhu & 1 & 0,2 & 0,571 & 0,461 \\
\hline
\end{tabular}

Selain itu, laju pengambilan pakan tidak dipengaruhi oleh interaksi antara perlakuan suhu dan waktu pemberian 
pakan. Hal ini terlihat pada karang lunak Sarcophyton sp. $(P=$ $1,000)$ dan Sinularia sp. $(P=0,461)$. Penurunan laju pengambilan pakan pada kedua jenis fragmen karang lunak ketika diinkubasi pada suhu $31^{\circ} \mathrm{C}$ ditunjukkan pada (Gambar 4) dan hasil analisa Two Way ANOVA ditunjukkan pada (Tabel 1).


Gambar 4. Penurunan laju pengambilan pakan pada kedua jenis fragmen karang lunak ketika diinkubasi pada suhu $26^{\circ} \mathrm{C}$ dan $31^{\circ} \mathrm{C}$.

\subsubsection{Analisa Independent Sample T-Test}

Grafik rata-rata laju pengambilan pakan antara karang lunak Sarcophyton sp. dan Sinularia $s p$. baik pada suhu $26^{\circ} \mathrm{C}$ maupun suhu $31^{\circ} \mathrm{C}$ ditunjukkan pada (Gambar 5).
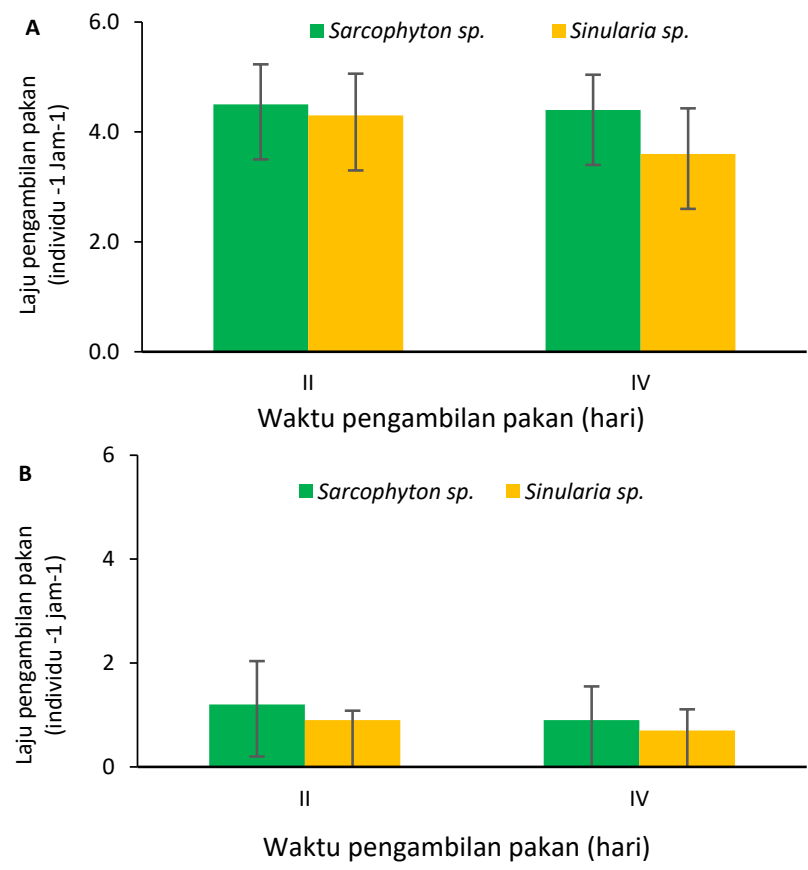

Gambar 5. Rata-rata laju pengambilan pakan antara karang lunak Sarcophyton sp. dan Sinularia sp. baik pada suhu $26^{\circ} \mathrm{C}$ dan $31^{\circ} \mathrm{C}$
Laju pengambilan pakan antara karang lunak Sarcophyton sp. dan Sinularia sp. baik pada suhu $26^{\circ} \mathrm{C}$ maupun suhu $31^{\circ} \mathrm{C}$ menunjukkan bahwa tidak terdapat perbedaan signifikan rata-rata laju pengambilan pakan antara karang lunak Sarcophyton sp. dan Sinularia sp. pada suhu $26^{\circ} \mathrm{C}$ hari kedua pemberian pakan dan hari keempat $(P=0,145)$ serta antara karang lunak Sarcophyton sp. dan Sinularia sp. pada suhu $31^{\circ} \mathrm{C}$ pada hari kedua maupun hari keempat pemberian pakan $(P=$ $0,722)$.

\subsection{Pembahasan}

3.2.1. Laju pengambilan pakan pada karang lunak Sarcophyton sp. dan Sinularia sp. pada Suhu $26^{\circ} \mathrm{C}$ dan $31^{\circ} \mathrm{C}$ pada perbedaan waktu pemberian pakan

Laju pengambilan pakan antara kedua jenis karang lunak tidak berbeda signifikan baik pada $26^{\circ} \mathrm{C}$ maupun $31^{\circ} \mathrm{C}$. Hal ini dapat mengindikasikan bahwa kedua jenis karang lunak memiliki toleransi suhu yang relatif sama. Sesuai dengan hasil penelitian Sammarco dan Strychar (2013) karang lunak $S$. ehrenbergi dan Sinularia lochmodes menunjukkan kerentanan serupa pada suhu tinggi dimana sel zooxanthella pada kedua jenis memiliki persentase peningkatan dan penurunan sel zooxanthella pada suhu berbeda yang serupa seperti pada percobaan suhu $34^{\circ} \mathrm{C}$ terjadi kenaikan persentase se zooxanthella pada $S$. lochmodes namun terjadi penurunan sel zooxanthella pada $S$. ehrenbergi, namun saat terjadi penurunan persentase sel inang pada $S$. ehrenbergi persentasenya lebih tinggi dibandingkan persentase penurunan sel pada inang $S$. lochmodes. Menurut Varghese et al. (2012), karang lunak masih dapat melakukan pengambilan pakan saat mengalami stres suhu untuk mempertahankan hidupnya. Namun belum diketahui efek jangka panjang dari stres suhu (peningkatan suhu) tersebut, apakah dapat meningkatkan kemampuan karang lunak untuk beradaptasi pada suhu tinggi.

\subsubsection{Pengaruh peningkatan suhu}

Peningkatan suhu yang dilakukan dalam percobaan laju pengambilan pakan pada karang lunak Sarcophyton sp. dan Sinularia sp. ketika diinkubasi pada suhu $31^{\circ} \mathrm{C}$ menunjukkan bahwa suhu yang tinggi menghambat pengambilan pakan pada kedua jenis fragmen karang. Walaupun polip pada kedua karang lunak telah terlihat keluar pada perlakuan suhu $31^{\circ} \mathrm{C}$, namun laju pengambilan karang lebih rendah pada suhu $31^{\circ} \mathrm{C}$ dibandingkan pada suhu $26^{\circ} \mathrm{C}$. Hasil eksperimen ini sesuai dengan penelitian yang dilakukan Coma et al. (2015) dimana kenaikan suhu dari $13^{\circ} \mathrm{C}$ sampai $21^{\circ} \mathrm{C}$ selama 8 jam di perairan Mediterania menunjukkan penurunan laju pengambilan pakan pada karang lunak Eunicella singularis. Hal ini diduga karena kenaikan suhu menurunkan metabolisme pada karang, sehingga walaupun karang dapat melakukan pengambilan pakan namun tidak optimal.

\subsubsection{Waktu pemberian pakan}

Waktu pemberian pakan tidak memberikan pengaruh yang signifikan ( $P>0,05$, Tabel. 1$)$ terhadap laju pengambilan pakan pada kedua perlakuan suhu pada karang lunak Sarcophyton sp. dan Sinularia sp. Hal ini mengindikasikan bahwa stres yang dialami karang lunak ketika diinkubasi pada suhu tinggi $\left(31^{\circ} \mathrm{C}\right)$ dapat mengganggu metabolisme tubuhnya sehingga menghambat proses pengambilan pakan dan proses ini terus terjadi selama karang lunak diinkubasi pada suhu tersebut. 
Laju pengambilan pakan pada karang lunak Sarcophyton sp. dan Sinularia sp. tidak berbeda signifikan baik pada suhu $26^{\circ} \mathrm{C}$ maupun $31^{\circ} \mathrm{C}$ pada semua waktu pemberian pakan, diduga karena kedua jenis karang memiliki toleransi suhu yang relatif sama. Walaupun tipe zooxanthella pada kedua karang lunak ini tidak diuji, tetapi kemungkinan memilikli tipe yang sama sehingga memiliki respon terhadap suhu yang sama. Hal ini sesuai dengan hasil penelitian Strychar et al. (2005) dimana karang lunak S. ehrenbergi dan Sinularia sp. masih dapat bertahan hidup ketika diinkubasi pada suhu diatas $31^{\circ} \mathrm{C}$. Selain itu, kedua jenis karang lunak tersebut memiliki tipe zooxanthella yang sama yaitu clade C (Strychar et al., 2005).

\subsubsection{Interaksi suhu dan waktu pemberian pakan}

Perlakuan peningkatan suhu dan waktu pemberian pakan secara bersama-sama menunjukkan perbedaan yang tidak signifikan ( $P>0,05$, Tabel. 1$)$ terhadap laju pengambilan pakan pada karang lunak Sarcophyton sp. dan Sinularia sp. Hal ini diduga karena peningkatan suhu $\left(31^{\circ} \mathrm{C}\right)$ telah menghambat proses pengambilan pakan selama kedua karang lunak diinkubasi pada suhu tersebut yang terlihat dari nilai yang tidak signifikan berbeda baik ketika hari kedua maupun keempat $(P>$ 0,05 ). Selain itu, hal tersebut dapat dimungkinkan karena kepadatan pakan dan kondisi pemberian pakan yang sama antara hari kedua dan hari keempat. Penelitian yang dilakukan Siang et al. (2009) juga menunjukkan waktu pemberian pakan tidak mempengaruhi laju pengambilan pakan pada karang keras Galaxea fasicularis ketika kondisi pemberian pakan sama.

\section{Ucapan penghargaan}

Penulis mengucapkan terimakasih kepada Laboratorium IImu Kelautan, Fakultas Kelautan dan Perikanan, Universitas Udayana, yang telah memfasilitasi pelaksanaan penelitian ini dan PT. Dinar Darum Lestari yang telah menyediakan sampel karang lunak.

\section{Bibliografi}

Akbar, I., Adi. W., Umroh, 2016. Pola sebaran karang lunak (Soft Coral) terhadap kedalaman yang berbeda di Pantai Turun Aban, Tanjung Pesona dan Rebo: Effect of Density Depth Against Soft Coral in Turun Aban Beach, Tanjung Pesona and Karang Kering. Jurnal Sumberdaya Perairan. $10,14-21$

Aratake, S., Tomura, T., Saitoh, S., Yokokura, R., Kawanishi, Y., 2012. Soft Coral Sarcophyton (Cnidaria: Anthozoa: Octocorallia) Species Diversity and Chemotypes. Journal Chemotype Diversity of Sarcophyton. 7(1), 10.

Burmester, E.M., Breef, P.A., Lawrence, N.F., Kaufman, L., Finnerty, R.J., Rotjan, R.D., 2018. The impact of autotrophic versus heterotrophic nutritional pathways on colony health and wound recovery in corals. Journal Ecology and Evolution. 8, 10805-10816.

Coma, R., Llorente, L.E., Serrano, E., Maria, G.J., Ribes, M., 2015. Natural heterotrophic feeding by a temperate octocoral with symbiotic zooxanthella: a contribution to understanding the mechanisms of die-off events. Jurnal Coral Reefs. 34, 549-560.

Ferrier, C., Rottier, C., Beraud, E., Levy, O., 2010. Experimental assessment of the feeding effort of three scleractinian coral species during a thermal stress: Effect on the rates of photosynthesis. Journal of Experimental Marine Biology and Ecology, 118-124.

Goldberg, W., 2018. Coral Food, Feeding, Nutrition, and Secretion. Buku: Marine Organisms as Model Systems in biology and medicine. 377 - 42.

Hoogenboom, M.O., Campbell, D.A., Beraud, E., DeZeeuw, K., Ferrier, C., 2012. Effects of Light, Food availability and temperature stress on the function of photosystem II and photosystem I of coral symbionts. 7, 1-13.

Mannuputty A.E.W., 2016. Karang Lunak (Octocorallia: Alcyonacea) di Perairan Biak Timur. Jurnal Oseanologi dan Limnologi di Indonesia. 1 (2): 47-59

Manuputty, A.E.W., 2002. Karang lunak (Soft Coral) Perairan Indonesia (Buku I, Laut Jawa dan Selat Sunda). Lembaga IImu Pengetahuan Indonesia. Jakarta. 91.

Migne, A., Davoult, D., 2002. Experimental nutrition in the soft coral Alcyonium digitatum (Cnidaria: Octocorallia): removal rate of phytoplankton and zooplankton. Université du Littoral Côte d'Opale, UPRES France. 43, 916.

Muscatine, L., McCloskey, L.R., Marian, R.E., 1981. Estimating the daily contribution of carbon from zooxanthella to coral animal respiration. Association for the Sciences of Limnology and Oceanography. 26, 601-61.

Parrin, A.P., Goulet T.L., Yaeger, M.A., Bross, L.B., McFadden, C.M., Blackstone, N.W., 2016. Symbiodinium migration mitigates bleaching in three octocoral species. (abstract) Journal of Experimental Marine Biology. 474, 73-80.

Raharjo S, 2019. Olah Data Statistik dengan SPSS. SPSS Indonesia 2014-2019. (https://www.spssindonesia.com/ (diakses 12 Mei 2020))

Raharjo S, 2018. Olah Data Statistik dengan SPSS. SPSS Indonesia 2014-2019. (https://www.spssindonesia.com/ (diakses 12 Mei 2020))

Ruwaimana M, 2013. Perbandingan aktivitas antibakteri ekstrak metanol Sinularia, Sarcophyton dan Lobophytum dari Perairan Tulamben, Bali. (Skripsi). Yogyakarta: Fakultas Teknobiologi, Universitas Atma Jaya Yogyakarta Program Studi Biologi. 22 hal.

Sammarco, P.W., Strychar, K.B., 2013. Responses to high seawater temperatures in zooxanthellate octocorals. Journal Pone. 8(2), 1-20.

Surakusumah, Wahyu., 2011. Perubahan Iklim dan Pengaruhnya terhadap Keanekaragaman Hayati. Makalah Perubahan Lingkungan Global. 1-24.

Siang, H.Y., Lin, S.C., Liew, H.C., 2009. Feeding of scleractinian coral, Galaxea fascicularis, on Artemia salina nauplii in captivity. Article in Aquaculture International. 17, 363376.

Strychar, K.B., Coatesa, M., Sammarcoc, P.W., Pivab, T.J., Scotta, P.T., 2005. Loss of Symbiodinium from bleached soft 
corals Sarcophyton ehrenbergi, Sinularia sp. and Xenia $\mathrm{sp}$. Journal of Experimental Marine Biology and Ecology. 320 (2005), $159-177$.

Towle, E.K., Enochs, I.C., Langdon, C., 2015. Threatened Caribbean Coralls able to Mitigate the Adverse Effects of Ocean Acidification on Calcification by increasing feeding rate. PLoSONE 10(4), 1-17.

Van O.L.P., Benayahu, Y., McFadden, C.S., 2013. Sinularia leptoclados (Ehrenberg, 1834) (Cnidaria: Octocorallia) re-examined. International Commission on Zoological Nomenclatur. 272, 29-59.

Varghese, M., Thomas, V.J., Joshi, K.K., Ignatius, B., Vinod, K., Naomi, T.S., Manisseri, M.K., Rani., Mary, G.R., 2012. Culture of The Soft Coral, Lobophytum pauciflorum (Family: Alcyoniidae) under captive conditions at Kochi, India. Central Marine Fisheries Research Institute, Kochi. Marine Fisheries Information Service T\&E Ser. 214, 201. 